\title{
Guoxue Re and the Ambiguity of Chinese Modernity
}

Xie Shaobo

\section{(2) OpenEdition \\ 1 Journals}

Electronic version

URL: http://journals.openedition.org/chinaperspectives/5378

DOI: 10.4000/chinaperspectives.5378

ISSN: 1996-4617

\section{Publisher}

Centre d'étude français sur la Chine contemporaine

\section{Printed version}

Date of publication: 1 January 2011

Number of pages: $39-45$

ISSN: 2070-3449

\section{Electronic reference}

Xie Shaobo, «Guoxue Re and the Ambiguity of Chinese Modernity », China Perspectives [Online], 2011/1 | 2011, Online since 30 March 2014, connection on 28 October 2019. URL : http:// journals.openedition.org/chinaperspectives/5378; DOI : 10.4000/chinaperspectives.5378 


\title{
Guoxue Re and the Ambiguity of
}

\section{Chinese Modernity}

XIE SHAOBO*

\begin{abstract}
This essay addresses the symbolic or socio-ideological significance of what is called guoxue re in China today. In the author's view, as a concept with a fixed morphological form, guoxue has been traversing history with a changing content, and for different people or social groups it means different things and serves different interests. The catachrestically used term guoxue acquires an imploding ambiguity when it is manipulated to accommodate different needs and desires in the contemporary Chinese culture and commodity market. The kaleidoscopic vertiginous guoxue landscape in China, the essay argues, ultimately points to an unmistakable collusion among the state government, the academic elite, and the commodity market. As such, the imploding ambiguity of the concept and discourse of guoxue bears a continuity with the ambiguity of Chinese modernity, which at present is a conglomerate of capitalism, Marxism, Confucianism, economism or developmentalism, and harmonious society. Moreover, the contemporary guoxue re betrays an innermost desire in the Chinese national unconscious for a different genuinely existing social order, and for other ways of being human than those defined by capitalist modernity while China is being dominated by the rule of capital.
\end{abstract}

KEYWORDS: guoxue, ambiguity, Confucian values, modernity, market, capitalism

T his essay does not claim to be about guoxue (Chinese national learning); rather, it deals with what is called guoxue re or the guoxue movement in contemporary China and the issues surrounding it. (1) With no systematic training in ancient Chinese classics and Chinese philology to qualify myself as an expert on guoxue itself - and I presume there are not many in contemporary China or overseas qualified for the title - I wish to speak to the symbolic or socio-ideological significance of the return of guoxue in China when the social and cultural context for its formation and practice is over, namely, the various uses that have been made of it.

\section{Guoxue: The ambiguous legacy}

Although there is no single universally acceptable definition of guoxue, the term always seems to signal a certain definite spectral existence of something symbolic of China and traditional Chinese culture in the minds of those who use it. As a concept with a fixed morphological form, guoxue has been traversing history with a changing content, and to different people or social groups it means different things. As uses of the past are always made to serve the interests of the present and, as Croce has noted, all history is contemporary history, ${ }^{(2)}$ I begin this essay with a number of questions as follows: What is guoxue? When did the term begin to be used? Why do the Chinese constantly invoke guoxue? What is the significance of the revival of guoxue in contemporary China when capitalist globalisation is taking over in the country as elsewhere in the world? How does it betray Chinese anxieties towards their nation's present and future? What is the symbolic meaning of guoxue in contemporary China if, as a trope, it is oftentimes a catachrestically floating signifier without a fixed semantic anchorage? How does the ambiguity of guoxue as such reflect the ambiguity of Chinese modernity or socialism with Chinese characteristics if the concept of guoxue is a product of modernity? Is there some national subconscious underpinning the double ambiguity?

Since its first appearance in 1902 when Liang Qichao (梁啟超) , one of the universally acknowledged guoxue masters, used the term guoxue in his correspondence with Huang Zunxian (黃遵憲), (3) guoxue both as a concept and as a discipline of academic research has been subject to different interpretations. According to Zhang Taiyan (章太炎), guoxue is a nation's indigenous learning: "Guoxue is the founding source of a country, and in a world dominated by rivalry, it is impossible for a nation to survive while its indigenous learning is on the decline. To my best knowledge there have been nations perishing with their inherent learning thriving on, and yet there has been no record of nations surviving while their indigenous learning has been eliminated." (4) In his Guoxue gailun (An Outline of Guoxue),

Xie Shaobo teaches in the Department of English at University of Calgary. He is Book Review Editor of ARIEL. He has published on literary theory, postcolonial studies, cultural studies, globalisation, comparative literature, translation, and Chinese modernity. His other works include: Cultural Critique and Critical Culture, New Directions in Postcolonial Studies (ARIEL 40th anniversary special issue co-edited with Wang Ning), Dialogues on Cultural Studies: Interviews with Contemporary Critics (co-edited with Fengzhen Wang), and Cultural Politics of Resistance.

1. I owe heart-felt thanks to Arif Dirlik for adding excellent titles to different sections of the essay.

2. See Collingwood, R.G., The Idea of History, Oxford, Oxford University Press, 1946, p. 289.

3. Huang Zunxian (1848-1905), well known for his innovative poetry, was a poet, diplomat, statesman, and educator in the late Qing Dynasty. For the inauguration and evolution of guoxue, see Arif Dirlik, "Guoxue/National Learning in the Age of Global Modernity" included in this issue. With a splendid genealogical description of guoxue with its key concerns, anxieties, problems, and pitfalls, Dirlik cogently points out the parallels between the emergence of guoxue in the early twentieth-century China and the politics of kokugaku in Japan that had its beginnings in the late seventeenth century and "reached its height" in the early nineteenth century. Both guoxue and kokugaku are characterised by an anxiety to find cultural resources for reinventing the nation, to break with a present that is responsible for the degeneration of the nation, and to replace the actual, living national identity with an imagined one.

4. See Tang Zhijun (湯志均), "Preface to Guoxue Gailun” (An outline of Chinese national learning), in Zhang Taiyan, Guoxue Gailun, Shanghai, Shanghai guji chubanshe, 2008, pp. 1-17, p. 6. This and all other translations in this essay are my own. 
Zhang breaks guoxue into three aspects or components, respectively named jingxue de paibie (studies of six classics), zhexue de paibie (schools of philosophy), and wenxue zhi paibie (trends and styles of literary writing). What is worth noting here is that in his discussion, guoxue with its three components includes all that has been written or produced in China over the past 4,000 years, literarily, philosophically, artistically, geographically, and even medically. ${ }^{(5)}$

Zhang's definition of guoxue is echoed by Deng Shi (鄧實), writing a few years later. In Deng's view, guoxue "is what inherently pertains to a nation. ... Where there are nations there is national learning. National learning is to be acquired to serve the nation's interests and manage its affairs. The birth of guoxue comes with the emergence of the nation; it is geographically differential and is rooted in the nation's character. As such it cannot be abandoned for a single moment." (6) In Deng's interpretation, guoxue comes closest to what is called a nation's entire traditional culture. Such an inclusive definition of guoxue finds support in other world-renowned scholars such as Liang Qichao and Hu Shi (胡適). In his recommended lists of guoxue works motivated by his anxiety for younger generations to carry on the nation's past legacies, Liang included, in pretty much the same manner, various kinds of Chinese writing ranging from Sishu wujing (four books and five classics), Zhuzi baijia (Writings of pre-Qin philosophers) and their study, philological works, poetry, and miscellaneous essays. (7) In his estimate, "our indigenous learning" will never perish; instead, it will acquire new life from the "true spirit of foreign learning" spreading far and wide in China, as long as "the transmitters and translators of foreign learning are well versed in guoxue." (8) The over-inclusiveness of Hu Shi's definition of guoxue is encountered in his remarks made in the "Inaugural Manifesto" for Guoxue Quarterly. '"Guoxue' in our eyes is merely the abbreviation of 'guogu' (國故, traditional Chinese culture and learning). All of China's cultural history is our 'guogu'; the study of the Chinese cultural history is 'guoguxue,' hence 'guoxue."' (9)

In a corrective response to the afore-mentioned broad definitions of guoxue, scholars such as Ma Yifu (馬一浮) ${ }^{(10)}$ named a much narrower range of works for the canon of guoxue: "Here I define guoxue as the learning of liuyi [six classics]; it is comprehensive, inclusive, and profound to bring all China's traditional learning under the rubric of Liu yi zhi xue [the learning of six classics]." (11) When faced with the problem of the term guoxue, Qian Mu (錢穆), (12) one of the most influential Chinese historians and masters of guoxue in modern China, self-consciously remarked in his preface to Guoxue Gailun (An Outline of Guoxue), "Learning has no national boundary. The term guoxue is a contemporary coinage with no history and no future certainty. With regard to its range of coverage, what should be included as guoxue, and what not? This is hard to determine. In this book, which has been written as an academic textbook, I have had to follow the model of Liang Qichao's Qingdai xueshu gailun [Introduction to the Scholarship of the Qing Dynasty], providing here a periodising approach to the Chinese tradition of scholarship and learning. Briefly commenting on each period's scholarly and intellectual trends, it is my intention to help readers secure a good command of the itinerary of China's evolving learning and thought over the past 2,000 years, nurturing their ability to make new beginnings in creatively inheriting the past." (13) While calling attention to the difficulty of achieving universal agreement on the content and coverage of the concept of guoxue, Qian in his book gives the reader to understand that he has chosen to narrow down what he means by guoxue to xueshu sixiang (national thought learning); for the works dis- cussed in the book are primarily sishu wujing ${ }^{(14)}$ and xianqi zhuzi as well as subsequent scholars and philosophers of different historical periods explicating and appropriating them or debating with one another about them. Qian Mu's conception of guoxue is shared by three other leading scholars, Mou Zongshan, ${ }^{(15)}$ Xu Fuguan (徐複觀), ${ }^{(16)}$ and Tang Junyi, ${ }^{(17)}$ for in their co-authored 1958 manifesto on Chinese intellectual achievements and culture they repeatedly use xueshu wenhua (學術文化), xueshu sixiang, and lishi wenhua xueshu (歷史文化學術) to refer to what they believe constitutes the spirit and itinerary of Chinese history. These three terms can be respectively rendered into English as "intellectual culture," "learning and thought," and "historical intellectual culture." In a literal sense, it seems erroneous to translate wenhua xueshu into "intellectual culture," but upon close reading and taking into account the context in which the term appears, I believe this English translation to be closest to the Chinese original. ${ }^{(18)}$

By now we have collected three different definitions of guoxue: 1) all the past learning, thought, literature, and cultural legacies that have been produced in China up to the close of the nineteenth century; 2) studies of the six classics; and 3) classical Chinese thought and learning. These mutually conflicting yet complementary definitions of guoxue not only testify to the unending historical debate or uncertainty regarding guoxue, but are the seed of confusion and inconsistency surrounding the contemporary guoxue re.

\section{Contemporary reincarnations}

The ambiguity or uncertainty attending the discourse of guoxue in the early twentieth century has persisted into today's guoxue movement in China. Such ambiguity and uncertainty has much to do with the ambiguity of Chinese modernity and Chinese self-knowledge. There are different versions of guoxue: guoxue for business people, guoxue for state officials or

5. See Zhang Taiyan, Guoxue Gailun, op. cit., pp. 16-59.

6. See Tang Zhijun, op. cit., p. 6 .

7. See Liang Qichao, Liang Qichao jiang guoxue (Liang Qichao's Essays on Guoxue), Nanjing, Fenghuang chuban she, 2008, pp. 4-20.

8. Liang Qichao, Lun zhongguo xueshu sixiang bianqian zhi dashi (On the transformation and development of ancient Chinese thought and learning), Shanghai, Shanghai guji chuban she, p. 110.

9. See Liu Mengxi, "Guoxue bianyi" (On definitions of guoxue), Wenhuibao, 12 April 2009, consulted on 16 July 2010.

10. Ma Yifu (1883-1967), a famous philosopher, guoxue master, and calligrapher, was a leading representative of Neo-Confucianism in modern China.

11. Ibid.

12. Qian Mu (1895-1990) was one of the leading historians and guoxue masters in modern China. Among his most influential works are Xianqin zhuzi xinian (Biographical chronicles of pre-Qin philosophers and scholars), Zhongguo jin sanbai nian xuexhu shi (A Chinese intellectual history of the last 300 years), Guoshi dagang (An outline of Chinese history), and Guoxue gailun (An outline of guoxue).

13. Since its first publication in 1920, Qingdai xueshu gailun (An outline of the intellectual history of the Qing dynasty) has always been regarded as a must for students of Chinese history. In this insightful book, Liang Qichao makes a full investigation of the intellectual development of the Qing dynasty, covering almost all scholars and their works pertaining to the period.

14. Sishu refers to Daxue (Great Learning), Zhongyong (The Doctrine of the Mean), Lunyu (The Analects of Confucius), Mengzi (Mencius); Wujing (Five Classics) refers to Shangshu, Shijing (Book of Poetry), Yijing, (Book of Change), Lijing (Book of Ritual), and Chunqiu (The Spring and Autumn Annals).

15. Mou Zongsan (牟宗三, 1909-1995), a philosopher and guoxue master, was a leading champion of NeoConfucianism in twentieth-century China.

16. Xu Fuguan (1904-1982) was a leading Neo-Confucianist in modern China, well-known for his original insights into Chinese culture and art.

17. Tang Junyi (1909-1978), philosopher and educator, was one of the leading figures of Neo-Confucianism.

18. See Mou, Zongsan, Xu Fuguan, and Zhang Junmai (張君勱), "Wei zhongguo wenhua jinggao shijie renshi xuanyan" (A manifesto on the reappraisal of Chinese culture), Wangshang dushu yuandi, 5 May 2006 (consulted on 16 July 2010). 
party cadres, guoxue for little kids in elementary school, guoxue for university research centres or guoxue academies, guoxue for media celebrities such as Yi Zhongtian (易中天) and Yu Dan (于丹) and their followers, etc. Obviously, guoxue in such varied contemporary contexts has become a loosely floating signifier severed from its signified. The tension attending the public's catachrestic use of guoxue has been largely informed and guided, consciously or unconsciously, by the writings of contemporary guoxue experts. Let's take a look, for instance, at an essay entitled "Lun guoxue de dangdai xingtai he dangdai yiyi" (On the Contemporary Forms and Meanings of Guoxue) by Yuan Xingpei (袁行霧), one of the leading scholars on classical Chinese literature and culture and Director of Beijing University's Guoxue Academy. In Yuan's article, guoxue fluctuates between traditional Chinese learning and the research and scholarship dealing with it. In other words, it wavers between guoxue as a discipline of study whose object of investigation is traditional Chinese learning and thought and guoxue as the corpus of classics of Chinese learning. In the beginning paragraph of his article, Yuan notes, "One can say that 'guoxue' refers to China's indigenous learning and thought as well as the scholarship dealing with traditional Chinese classics, learning, and culture." (19) The duplicity or ambiguity of the definition of guoxue embraced by Yuan emblemises the persistent uncertainty of the term throughout his article. When he remarks that guoxue emerged to meet the new trends of thought at the turn of the twentieth century and safeguarded traditional Chinese culture, and when he asserts that guoxue must carry forward splendid traditional Chinese culture, and that there is an urgent need for a new guoxue, obviously what guoxue means is the discipline of study investigating traditional Chinese thought and learning instead of the object of the study. On the other hand, guoxue in Yuan's article also refers to the collection of traditional Chinese classics. When he quotes Deng Shi and Huang Jie creating Guocui xuebao to investigate guoxue and preserve guocui, and when he cites Zhang Taiyan's categorisating of guoxue into xiaoxue (philology), jingxue (the study of six classics), shixue (history), zhuzi (pre-Qin masters), and wenxue (literature), the term unmistakably refers to traditional learning and classics that the discipline of study called guoxue takes as the object of investigation. Another ambiguity in Yuan is his conflation of guoxue and traditional culture after he defines the former as the core values and assumptions underwriting the latter. ${ }^{(20)}$

If Yuan Xingpei's conception of guoxue is confusing and misleading, then a more aggravated version of ambiguity or ambivalence is encountered in Zhang Rulun (張汝倫), another leading guoxue scholar in contemporary China. In his intervention, (21) Zhang raises the status of guoxue to the altitude of universal significance and validity while emphasising the indigeneity of it and turning guoxue into a Chinese equivalent for American Studies. (22) In introducing this confusion, Zhang only manages to cast doubt on himself as a well-informed and trustworthy scholar. There is a double incongruence between American Studies and guoxue: first, American Studies was founded at a moment when the US was emerging as a global power with increasing influence upon the world, whereas guoxue was born as China was being reduced to the status of a semi-colonised country, its traditional culture being superseded by invading modern Western culture, although both were propelled by an unmistakable ethnocentrism. Second, while guoxue refers to a corpus of cultural and scholarly classics produced during a span of over 3,000 years up to the end of the Qing dynasty, the term American Studies designates a discipline of scholarly and critical in- quiry whose generic and historical frontiers keep shifting to include the latest cultural productions. Since the 1960s and 1970s, American Studies has reinvented itself, shifting its focus to issues of race, ethnicity, gender, sexuality, immigration, and transnational concerns. In grandiosely asserting universality with excessive fervour, Zhang Rulun seems to risk a strong danger of falling into some kind of logical inconsistency and sinocentric arrogance that ultimately undermines the cause he intends to promote. Some of Zhang's expressions confirm that advocates of guoxue, as underlined by Arif Dirlik, could easily be trapped in a parochial sinocentrism, especially if they do not open up enough to other non-Western cultural legacies in seeking possibilities of alternative modernity. ${ }^{(23)}$ To any informed reader, Zhang's sinocentric celebration of the universal value of guoxue registers the larger context of contemporary debate on universalism between two opposed camps in China. One camp advocates freedom, equality, democracy, and human rights as universal values, and in their view, to strive for these values is to prevent the state's complete control over a nation's economic, political, cultural, and social life. As such these values should be in no way compromised or sacrificed in the name of safeguarding national characteristics. ${ }^{(24)}$ The other camp, to which belongs Zhang Rulun himself, questions and rejects these values as Eurocentric or Westcentric, for they are West-authored and West-authorised, and in their ideological deployment have been instrumental in serving Western territorial and economic expansionism. Instead, members of this latter camp assert the Chinese concept of hexie (和諧, harmony or social harmony) as a truly universal value, which in their view subsumes or implies all of the aforementioned Western values. ${ }^{(25)}$ These two positions, though apparently opposed to each other, can be taken as flip sides of the same coin, for both endorse universalism - it is just that the values universalised are different. What both neglect is that thoughts and values are place-related, (26) that the concept of universality has culture-specific articulations, and that universal values migrating across cultural borders have to undergo revision or modification. (27)

If guoxue in Yuan Xingpei and Zhang Rulun respectively is a concept loaded with ambiguity and sinocentrism, then it becomes a magical word for other scholars. In his article entitled "Jianli makesi zhuyi xin guoxue guan he xin guoxue tixi" (Creating a Marxist New GuoxueTheory and Sys-

19. Yuan Xingpei, "Lun guoxue de dangdai xingtai he dangdai yiyi" (On the Contemporary Forms and Meanings of Guoxue), Zhonguo shehui kexueyuan yuanbao (Newsletters of the Chinese Academy of Social Sciences), 22 July 2008, consulted on 16 July 2010.

20. The notion of guoxue as core values and thoughts underpinning Chinese cultural practices is a key thesis argued in Qian Mu's Guoxue gailun (An outline of national learning), Beijing, The Commercial Press, 1997; and Zhongguo wenhua shi daolun (An introduction to the history of Chinese culture), Beijing, The Commercial Press, 1994.

21. Zhang Rulun, "Guoxue yu dangdai shijie" (Guoxue and the contemporary world), Wenhuibao, 23 June 2008 (consulted on 17 July 2010).

22. "American Studies," Wikipedia: The Free Encyclopedia, 13 October 2010, http://en.wikipedia.org/ wiki/American_studies, consulted on 28 September 2010.

23. See Footnote 1. Dirlik's essay is included in the present issue as well.

24. See Du Guang, "Pushi jiazhi: yige shidaxing de zhongda keti," (Universal values: An epochal project), 25 October 2010 (consulted on 21 November 2010); see also "Pushi jiazhi he zhongguo tese," (Universal Values and Chinese Characteristics), 27 July 2010 (consulted on 21 November 2010).

25. See Yu Dunkang, "Xunzhao zhongguo wenhua zhong de pushi jiazhi," (In search of universal values in Chinese culture), 9 October 2009 (consulted on 21 November 2010); Zhang, Weiwei, "Shui chuangzao le renlei de pushi jiazhi?" (Who has created universal values?), 1 July 2009 (consulted on 21 November 2010).

26. See Chakarabarty Dipesh, Provincializing Europe: Postcolonial Thought and Historical Difference, Princeton, Princeton University Press, 2000, xviii.

27. For more discussion on this topic, see Judith Butler, "Restaging the Universal and the Limits of Formalism," in Butler, Laclau, and Žižek, Contingency, Hegemony, Universality: Contemporary Dialogue on the Left, London and New York, Verso, 2000, pp. 11-43. 
tem), (28) for instance, Li Shenming (李慎明), vice president of the Chinese Academy of Social Sciences, notes, "The purpose of advocating guoxue in contemporary China is to carry forward the excellent cultural traditions of the various nationalities in China, to complete the sinicisation of Marxism, to facilitate development of a systematic theory of socialism with Chinese characteristics, to accomplish the historic task of rejuvenating China, to further reinforce the integrative unity of Chinese culture, to maintain the ideological basis of the solidarity of Chinese communities all over the world and their inseparable connection, to enhance the cultural exchange and cooperation between the Chinese on both sides of the Taiwan Strait with a view to expediting the reunification of China, to help satisfy the desire of other peoples of the world to understand China, to introduce traditional Chinese culture to the world, and to quicken the process of popularising outstanding Chinese culture in different parts of the world." (29) In the space of this over-stretched, lengthy sentence, one encounters some magical metamorphoses: Guoxue acquires an all-purpose usefulness and serves China's every state project. What Li's statement on guoxue betrays is an imploding ambiguity or incongruity of the term as well as his anxiety to turn guoxue into an instrument serving state interests. The same grandiloquent tone is detected in another scholar's similar assessment of guoxue: Relaunching and reconstructing guoxue today, in his view, is of enormous importance in building a socialist culture with Chinese characteristics. It helps to articulate Chinese cultural subjectivity, facilitates China's national renaissance, reinvigorates Chinese culture, and reasserts its beauty. ${ }^{(30)}$

Coinciding with such grandiloquent conceptual ambiguity of guoxue in academia are the numerous confusing uses it has been put to in the culture and commodity market of contemporary China. Even a casual catalogue of scenes and signs of the contemporary Chinese cultural landscape or market would lead to reflections on the imploding ambiguity of guoxue and the motivations behind it. All or at least most of the leading universities in China are running guoxue institutes or guoxue training classes, some of which are designed particularly for CEOs. There are all kinds of televised guoxue lectures forums, and a fairly large horde of emerging guoxue "masters" headed by Yu Dan, Yi Zhongtian, Fu Peirong, He Yizhou, Chen Zhaojie, Zhang Qicheng, and Qian Wenzhong, to name only a few, who have become media celebrities with large followings for their televised guoxue lectures on Zhuang Zi, Lunyu, Sanguo (Romance of Three kingdoms), Sanzijing (Three-Character Reader for Young Children), Hongloumeng (Dream of the Red Chamber), Xiyouji (A Journey to the West), and Yijing (Book of Change). In some provinces elementary school kids are made to memorise the Sanzijing while wearing pre-modern scholarly costumes, and bookstores are saturated with all kinds of books on the relationship between guoxue and administrative or managerial skills, enterprises, and careers. Let's take a look at the CEO guoxue seminars offered by a number of internationally known universities: Guoxue Academy at Renmin University of China (People's University of China) offered a doctoral seminar for Government and Business Leaders in 2009, covering subjects from sishu wujing to all kinds of ancient classics in the domains of history, medicine, art, literature, poetics, and religion. Peking University's Guoxue Academy in 2010 designed seminars on fengshui (風水, geomancy), zhanbu (占卜, augury), and government stratagems. Chinese Confucian Business Guoxue Academy earlier this year ran a guoxue seminar for CEOs and government department heads. Fudan University offered a CEO Guoxue Seminar in August 2010 covering sishu wujing, Lao Zi, Zhuang Zi, and Sun Zi's Art of War. (31) At the same time there are also entrepreneurial guoxue forums organised by big enterprises. For instance, in June 2010 Fujian Daimler Automotive Co., Ltd. co-sponsored China's Entrepreneurial Guoxue Forum with the magazine Chinese Entrepreneur discussing the contribution of guoxue to green ecoenvironment and the harmonious relationship among heaven, earth, humanity, and myriad things. In large cities such as Chongqing , Chengdu, Wuhan, Beijing, Guangzhou, Shenzhen, Nanning, Jinan, and Xiamen, guoxue is becoming a subject for elementary school kids. Small children not only recite Sanzijing, Lunyu, Xiaojing (On Filial Piety), and Dizigui (The Book of Principles and Rules for Children), but also practice meditation and qigong in Han-style clothes.

In CEO guoxue seminars offered by universities, guoxue is used as the source or treasury of wisdom, business stratagems, ethical codes of business behaviour, guides for personal fulfilment, keys to inner peace, and principles and techniques of moral cultivation. This is precisely what the business community embraces and is eager to buy, regardless of whether the offered guoxue seminars are able to achieve their projected goals or whether the thoughts and views of guoxue classics can actually meet those desires in a world centuries away from the world in which the guoxue classics as well as those thoughts and views were born and practiced. While business stratagems and personal fulfilment are at the top of the above-mentioned list of values, the rest are really felt needs in the contemporary Chinese business community as well. Not only does inner peace relate to personal fulfilment, but wisdom, business ethics, and character cultivation also contribute to it, for according to Chinese cultural tradition, the primary qualities of a highly esteemed and socially recognised successful businessman are transcendental wisdom, moral integrity, and adhesion to ethical principles, hence the name or concept of rushang (儒商) - an intellectual businessman well trained in guoxue or Confucian (the often camouflaged identification between the two terms will be taken up later in the essay) thoughts and values. Rushang refers to the kind of businessman who is not only well educated, wise, and knowledgeable, but whose behaviour is defined by ren, yi, li, zhi, xin. ${ }^{(32)}$ As the image of rushang in Chinese cultural imagining always recalls those winning qualities, it is a hot commodity among business people in China today. The tacit consensus among business people is that to be a rich man is a small success; to be a great success is to become a social or media celebrity, but to reach this grand goal money is not everything, and social, cultural, and moral trappings are more important. This is partly why and how there is a growing market demand for guoxue works and guoxue seminars, for these works and seminars can bring businessmen these necessary trappings. The prime push behind the burgeoning market is, of course, the marketisation and commodification of education in contemporary China, which drives people to seek commercial resources from all times and places past and present, transforming everything with cultural or historic value into a commodity. What makes one pause in the face of this growing market is that guoxue is not only made to serve the business world or the world of capital, but seems to be manipulated to accommodate every need or desire of the Chi-

28. Li Shenming. "Jianli makesi zhuyi xin guoxue guan he xin guoxue tixi" (Creating a Marxist new guoxue theory and system), Guangming ribao, 8 February 2010, (consulted on 17 July 2010).

29. See note 14 .

30. Ji Baocheng, "Guanyu zhenxing guoxue de sikao," (Thoughts on a reconstructed guoxue), 12 September 2007 (consulted 16 July 2010).

31. The tuition fees charged by the institutions range between 22,000 and 58,000 yuan.

32. These terms rendered in English respectively mean "humanity" or "benevolence," "righteousness," "ritual," "intelligence," and "faithfulness." 
nese. Such mystification of guoxue reaches a pinnacle in titles of publications such as Guoxue zhong de guanli zhihui (Managerial Wisdom in Guoxue), Guoxue yu rensheng (Guoxue and Living), Dangyuan lingdao ganbu ershi tang guoxue xiuyang ke (Twenty Guoxue Lectures on Character Cultivation for Party Leaders).

If the incongruent definitions of guoxue have effected irresolvable ambiguity, then the stretched use and imploding ambiguity of the concept deployed in contemporary China's culture and education market are pushing the concept to a crisis. When something becomes everything and serves every interest, it turns into nothing and no longer has any real use.

\section{Guoxue as ideology: The past and its present}

If the kaleidoscopic vertiginous guoxue landscape depicted above tends to reduce guoxue to an empty signifier, a closer look into its various uses will unmask the concealed symbolic and ideological significance and functions behind the guoxue fever. First, the return of guoxue in contemporary China coincides with the veiled capitulation of the Chinese regime to capitalism, and as such it serves an overall ideological project for the ambiguous modernity PRC champions; second, the logic of capital or the desire for profit is propelling the transformation of everything, past and present, material and immaterial, into a commodity, and the guoxue fever is major site of such commodification. Third, the academic sector of Chinese society has forfeited its right and ability to act as its intellectual and cultural guide, and what exists between Chinese academia and the political regime is collaboration or collusion rather than critical confrontation. Here arises the fundamental difference between Guoxue Studies conceived and practiced a century ago and at the turn of the twenty-first century. For, in its inaugural moment, not only was guoxue advocated and practiced by those who, well trained in guoxue and genuinely concerned and committed to promoting traditional Chinese learning, championed the sincere efforts to safeguard the core values of Chinese culture against the threat of the hegemonic Western learning instead of treating guoxue works as sign values and commodities as many of the "guoxue masters" are doing today, but the pioneers of Guoxue Studies were independent critical intellectuals, or what Edward Said calls public intellectuals. ${ }^{(33)}$ There is no doubt a continuity between the guoxue movement at the turn of the twentieth century and at the beginning of the twenty-first century, but that continuity consists more of shared ambiguity than of shared anxieties about the preservation or survival of traditional Chinese learning, or of any shared conscience and responsibility pertaining to the figure of the public intellectual.

When the guoxue pioneers such as Zhang Taiyan, Liang Qichao, and Liang Shuming were advocating guoxue, the whole nation was seized by worries and anxieties about the country's national and cultural survival in a new world dominated by the West-led and West-defined capitalist modernity that, predicated on free-market economy, Western rationalisation, and Western parliamentary democracy, was "batter[ing] down all Chinese walls," "compel[ling] all nations, on pain of extinction, to adopt the bourgeois mode of production." (34) This is the moment of what Michael Valdez Moses calls an "irreversible" "homogenizing worldwide process of modernization" (35) that had been newly set in motion, and which, in the name of progress, was threatening to conquer worldwide social communities and cultural modes of production that stood as "distinct," "legitimate," and "alternative" to modern society, heterogeneous possibilities of organising human society, different ways of gratifying individual desires and ambitions or of "being-in-the-world," and divergent systems of beliefs, mores, and values that are "radically different from those that have come to prevail in the twentieth century." (36) Meanwhile, China had by then been repeatedly humiliated by its defeat at war with Western powers and Japan, and many of the Chinese intellectuals or official-scholars had become convinced that in order to emulate and ultimately rival the West, China had to be Westernised - what one could call a strategic Westernisation, rejecting its own cultural past.

It is misleading to see the return of guoxue in China today as indicative of similar sentiments and anxieties about national and cultural survival. To illustrate this point, let's take a look at the historical context for the revival of guoxue in contemporary China. First, the economic successes of Japan and the four Asian mini-dragons have given rise to a global discourse and a socio-political imaginary of Confucian capitalism, which seems to challenge the world's established ideas of the tradition-modernity relationship. Second, a transcontinental group of Confucianist scholars has given rise to a School of New Confucianism and a theory of Cultural China, both of which not only contribute enormously to articulating East Asian or Confucian values "such as sympathy, distributive justice, duty-consciousness, ritual, public-spiritedness, and group orientation," but also to spreading the notion that modernity "may assume different cultural forms" and that all indigenous cultural traditions "throughout the world have the potential to develop their own alternatives to Western modernism." (37) Third, China is rising as a global economic power with an astonishing record of continuous GDP increases in the midst of economic recession in the rest of the world. All of these factors contribute to reviving world-wide interest in Confucian culture, and seem to convince many world leaders in government, political science, sociology, and cultural studies that Confucian values and cultural legacies offer potential opportunities for reinventing capitalist modernity. These factors also combine to reawaken the Chinese in China to the utilitarian importance of Confucian values. In other words, China's contemporary revival of interest in guoxue is motivated less by worries and anxieties about national survival and rejuvenation than by self-congratulatory feelings of national pride and narcissism.

It is very significant that guoxue made its first come-back gesture in China at a moment when the world was celebrating Confucian capitalism, and when it was universally proclaimed that socialism had become totally bankrupt and that History was reaching its end in global capitalism. The first official signal of guoxue's re-inauguration or return was a long article titled "Guoxue qiaoqiao zoujin beida xiaoyuan" (Guoxue is Quietly Coming Back to the Campus of Peking University), which was carried in the $16 \mathrm{Au}$ gust 1993 edition of The People's Daily, less than two months later, Guangming Daily published an article entitled "Guoxue he guoxue dashi de

33. See Edward Said, Representations of the Intellectual, New York, Vintage, 1996, pp. 58-63. According to Said, an intellectual is someone independent and undomesticated, who always "move(s) away from the centralizing authorities towards the margins," and who is "fundamentally about knowledge and freedom" and never takes anything for granted. Assessed against this definition, many academics in China today, unfortunately, do not deserve the title of intellectual.

34. Marx and Engels, The Manifesto of the Communist Party, in Lewis S. Feuer (ed.), Marx \& Engels: Basic Writings on Politics \& Philosophy, New York, Doubleday and Company, 1959, pp. 6-41, p. 11.

35. Moses, Michael Valdez, The Novel and the Globalization of Culture, New York, Oxford University Press, 1995, p. 6.

36. Ibid., p. xvi-xvii.

37. Tu Weiming (杜維明), "Multiple Modernities: A Preliminary Inquiry into the Implications of East Asian Modernity," in Lawrence E. Harrison and Samuel P. Huntington (eds.), Culture Matters: How Values Shape Human Progress, New York, Basics Books, 2000, pp. 256-266, p. 264. 
meili" (The Charm of Guoxue and Guoxue Masters). ${ }^{(38)}$ It seems superfluous to point out that The People's Daily and Guangming Daily are the two top official newspapers in China, and that whatever appears in them has to be approved by the Communist Party and represents the Party's will. These two publications can be taken as marking the official re-inauguration of guoxue in China. Viewed in such a historical context, one can argue, the advocacy of guoxue can be taken as a Dengist gesture of saying yes to Confucian capitalism. Actually, his formulation of "socialism with Chinese characteristics," which is a rerun of "capitalism with Chinese characteristics," can be read as a PRC version of "Confucian capitalism," because both of them involve a hybrid of tradition and modernity, and because Chinese characteristics are Confucian values renamed. Such close affinity between Confucian capitalism and socialism with Chinese characteristics becomes more obvious with the Party's call for "harmonious society" today, for at the core of Confucian values is the ideal of harmonious society. Indeed, guoxue is in actuality used as a catachrestic stand-in for Confucian values. From its first reappearance in contemporary China to its various conceptions among contemporary guoxue scholars as well as in the media and culture market, one can argue that guoxue actually refers to Confucian values and legacies without naming them. If, according to Yuan Xingpei, Zhang Rulun, Li Shenming, and Ji Baocheng (紀寶成) respectively, the essence of guoxue consists in its ability to enrich our spiritual world, to reinforce China's social cohesion and national unity, to open up ways of worlding alternative to those prescribed by capitalist modernity, and to maintain the solidarity of the Greater Cultural China, then the spectre of guoxue is none other than Confucianistic in essence. As universally acknowledged, Qian Mu is one of the most influential scholars on classical Chinese learning, and one of the few in the twentieth century deserving the title of guoxue master. What he indefatigably did all his life was, according to his disciple Yu Yingshi (余英時) and many others, to call back the spirit of guguo (故國, the lost China). ${ }^{(39)}$ Actually one can say that what Qian Mu devoted his whole life to doing was calling back the spirit of guogu (classical Chinese learning). And in Qian's estimate, what threads through the whole corpus of Chinese classical learning is Confucianism, a thesis argued in almost all his works. ${ }^{(40)}$ What he writes in Zhongguo shixue fawei (Essays on Chinese Historiography) is particularly illuminating here: Confucius stands as a central point in the 5,000-year Chinese history, creatively inheriting Chinese cultural traditions of the first 2,500 years and ushering in a Chinese whole way of living for the following 2,500 years. ${ }^{(41)}$ The difference between Qian and the contemporary guoxue scholars discussed earlier is that what Qian explicitly points out is only ambiguously or equivocally implied by them.

\section{An ambiguous modernity}

In his 2008 book In Defense of Lost Causes, Slavoj Zizek notes that China is the world's "ideal capitalist state" today, and that "as the emerging superpower of the twenty-first century [it] seems to embody a new kind of capitalism: disregard for ecological consequences, disdain for workers' rights, everything subordinated to the ruthless drive to develop and become the new world force." (42) "In order to curb the excess of social disintegration caused by the capitalist explosion," Zizek continues, "Chinese officials celebrate religions and traditional ideologies which sustain social stability, from Buddhism to Confucianism, that is, the very ideologies that were the target of the Cultural Revolution." (43) In his view, every cultural or theoretical legacy, from Confucianism to Marxism, is being mobilised by the Chinese govern- ment to "legitimize the present Chinese state interest of maintaining Communist Party power and thus guaranteeing stability in a period of fast-moving economic development." (44) What Zizek sees in China today, one can argue, is an imploding ambiguity of modernisation or modernity championed by the CCP leadership. Capitalism, Marxism, Confucianism, economism or developmentalism, and harmonious society, these contradictory terms constitute the parameters of the present phase of Chinese modernity.

The uncertainty attending "socialism with Chinese characteristics" and "socialist market economy" has triggered much heated debate on China's economic reform in China and overseas. "Socialist market economy" signifies a hybrid economy, while "socialism with Chinese characteristics" tends to reconcile two social systems apparently opposed to each other. Socialist market economy as practiced in China threatens to break down the boundary between capitalism and socialism. The defining hallmark of the PRC project of modernity is its ambiguity, and that is why world-renowned economists and sociologists such as Samir Amin and Giovanni Arrighi have noted in different contexts that socialism is not completely gone nor is capitalism fully established in China. ${ }^{(45)}$ However, the "theoretical ambiguity or uncertainty concerning contemporary Chinese socio-economic life does not preclude a much less ambiguous empirical reality":

\section{China's phenomenal advance in economic development is creating} a yawning gap between poor and rich, country and city, throwing the country into confusion and chaos at different levels of social life. The past 15 years or so have witnessed unprecedented rates of unemployment, disintegration of medical care and social welfare, institution of market economy at the cost of the principles of equality and social justice, emergence of an indigenous capitalist class, and a corrupt officialdom colluding with national and transnational capitalists. The nationwide redistribution of public property once again pushes the workers and peasantry to the margins of society. Urban space in China is being quickly modernized at the cost of the peasantry, which is politically the most deprived and economically the most exploited sector of the population. The whole country is dominated by the logic of capital, the desire for profit, and the commodified structure of consciousness. ${ }^{(46)}$

Zizek is precisely correct that it is in order "to curb the excess of social disintegration caused by the capitalist explosion" that the present Chinese government is recruiting and mobilising all kinds of religious, ideological, and cultural resources. It is in such a context that guoxue is returning to the Chinese cultural imagination and market. What the Chinese state think-tank really intends to recruit or resuscitate of guoxue or traditional

38. See the 14 October 1993 edition of Guangming Daily.

39. See Yu Yingshi, Qian mu yu xiandai zhongguo xueshu (Qian Mu and modern Chinese learning), Guilin, Guangxi Normal University Press, 2006, p. 16.

40. This thesis stands out particularly in his Guoxue gailun and Zhongguo wenhuashi daolun.

41. See Qian Mu, Zhongguo shixue fawei (Essays on Chinese historiography), Beijing, Sanlian Shudian, 2009, p. 232.

42. Žižek, Slavoj, In Defense of Lost Causes, London, Verso, 2008, pp. 190-191.

43. Ibid., p. 198.

44. Ibid., p. 200.

45. This is a rehash of what I have said in my answers to Barbara Foley's interview questions in Science \& Society, below.

46. Xie Shaobo, "Crossroads: China's future Under Debate: An Interview with Fengzhen Wang and Shaobo Xie," in Barbara Foley (ed.), Science \& Society, vol. 73, no. 2, 2009, pp. 193-207, p. 194. 
values and learning are primarily Confucian values such as social stability, harmonious interpersonal relations, collectivism, and self-cultivation. The green light granted to guoxue by the state is translated by the cultural, the educational, and the media market into "Anything goes." All those seminars, forums, school programs, televised lectures, and publications on guoxue, as hot commodities, are designed and manufactured to satisfy all kinds of desires: To make profit, to issue a certificate for proper moral conduct, to make a gesture of patriotism or nationalism, to offer a simulacrum of traditional culture, or to add a human face to capital. In all these pursuits, one sees an unmistakable collusion among Chinese academia, the market, and the ruling regime: what is at stake is a kind of simulacrum of something long lost, which is desired by state-officials, designed by academics, and produced by market promoters. If all these pursuits or performances, by the state-market-academia trinity, only signal the absence of what they are about, then, one can argue, they nonetheless obliquely reflect the presence of something underpinning the present Chinese society, an innermost nostalgic yearning among the Chinese for what is long lost - the Confucian values such as unity between Heaven and humanity, human-relatedness, social cohesion and harmonious interpersonal relations, and familial and societal solidarity prioritised over economic development. Such a cultural nostalgia for a long-lost past in the depths of ordinary people's minds is less an irrational insistence on going back in time than an effect of the Lacanian logic of lack. What triggers the desire for something is its absence. If Chinese state think-tanks, the commodity market, and academia are capitalising with a vengeance on such traditional values, it is mainly because they are cherished by the ordinary people. The only way any political regime can secure or maintain the people's support is by making believe that they are acting on their will; in much the same way, the only way the market can sell commodities successfully is by pretending that it is selling in the consumers' interest.

What Dipesh Chakrabarty writes in Habitations of Modernity about the politicians' use of khadi in India has particular bearing on the present discussion. ${ }^{(47)}$ Khadi is coarse, homespun cotton cloth that Ghandi wore and popularised in the 1920s. "The whiteness of khadi symbolizes the Hindu idea of purity (lack of blemish, pollution)," Chakrabarty explains, "its coarseness an identification with both simplicity and poverty; together, they stand for the politician's capacity to renounce his own material well-being, to make sacrifices (tyag) in the public/national interest. Khadi indicates the person's capacity to serve the country." ${ }^{(48)}$ After introducing the historical origins and socio-political symbolic significance of khadi or, more precisely, the wearing of it, Chakrabarty proceeds to relate that given the rampant official corruption in India, the use of khadi by politicians has lost its previous Ghandian significance and only betrays politicians' hypocrisy. What is shockingly fascinating and enlightening, however, is that, after speaking about politicians' hypocrisy, Chakrabarty makes another turn of the screw and argues that the use of khadi in contemporary India speaks of the fact that Indians still believe in the values symbolised by khadi, the values advocated by Ghandi. That is, although the politicians are corrupt despite their wearing of khadi, they as well as the Indian people still, though unconsciously, hold on to the values and virtues championed by Ghandi. The wearing of khadi indicates the unconscious or unintended desire for what khadi symbolised in Chandi's time - honesty and dedication to serving the country. If and when the Indians eschew khadi and Indian politicians no longer care to wear it, that would "signify the demise of a deeper structure of desire and would signify India's complete integration into the circuits of global capital." (49)
In much the same way, although the Confucian or traditional values and virtues as capitalised by the state government, the academic elite, and the commodity market in contemporary China only ironically mirror their absence among their advocates and the hypocrisy on the part of state officials and market promoters, the celebration of those values by the statemarket-academia trinity nevertheless speaks to the fact that the Chinese still believe in those values and virtues. It points to an innermost desire in the national unconscious for a different genuinely existing social order, and for other ways of being human than those defined by capitalist modernity. If and when the Chinese reject those Confucian values and Chinese politicians no longer make a point of advocating them, that will signal China's complete integration into capitalist modernity.

China today is an exemplary place for the nonsynchronic co-existence of different temporalities and different cultural practices. In other words, it is a layered society defined by what Raymond Williams terms different modes of culture - dominant, emerging, and residual. ${ }^{(50)}$ As a nation with a long history and a rich cultural heritage, whose entry into modernity was forced by the West and as such always evokes feelings of humiliation suffered by the Chinese at their defeat in war with Western powers (in a sense Japan counts as a Western power as well), China has always reacted to West-inaugurated and West-dominated modernity with a mind torn between emulating the Western Other and keeping its own cultural characteristics in constructing its own mode of modernity. This is a structure of feeling, to borrow a term from Williams again, that has been and remains to be shared by most of the Chinese. It is such a nationally shared persistent ambivalence towards tradition and modernity, or towards capitalist globalisation, that has been constantly manipulated by the Chinese government in deploying Confucian values to legitimise its authoritarian rule and in using the rhetoric of development to rationalise the present when the nation is threatened by increasing social stability. This is how and why everything there seems to have an aura of ambiguity, from common cultural gestures, to educational programs, to media images.

Guoxue is no exception to the rule. However, despite all its irresolvable ambiguity and the various uses to which it has been put, there is something crystal clear about guoxue: It has always been recalled from the past to serve a certain need in the present. It is oftentimes a moment of catachresis, but the catachresis points to something that refuses to die - the nostalgic desire in the national unconscious for some long-lost values and virtues, imagined or lived - and because of that, Chinese modernity may never be the same as the modernity outside its borders, at least not in the foreseeable future. It is in this sense that to separate the discussion of guoxue from the context of Chinese modernity, or to divorce the ambiguity of guoxue from the ambiguity of Chinese modernity, is to miss the whole point.

47. Dipesh Chakrabarty, Habitations of Modernity: Essays in the Wake of Subaltern Studies, Chicago, University of Chicago Press, 2002.

48. Ibid., p. 52.

49. Ibid., p. 64

50. See Raymond Williams, Marxism and Literature, Oxford, Oxford University Press, 1977, pp. 121-127. According to Williams, a cultural process or system has three aspects, respectively the dominant, the residual, and the emergent. The dominant refers to the "determinate dominant features" of the cultural system (121); the residual designates what was formed in the past but "is still active in the cultural process" as "an effective element of the present" (122); the emergent points to "the new meanings and values, new practices, new relationships and kinds of relationship" that are not only "continually being created" but stand "alternative or oppositional" to the dominant (123). While the dominant and the residual are quite easy to isolate from each other, it is much more difficult to distinguish between the new elements of the dominant culture and the alternative or oppositional emergent cultural features. 